\title{
Characteristics of sleep habits among adolescents living in the city of Ribeirão Preto (SP)
}

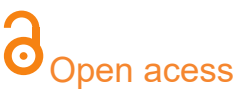

${ }^{1}$ Departament of Puericulture and Pediatrics, Ribeirão Preto Medical School, University of São Paulo

${ }^{2}$ Medical School, Federal University of São Carlos

\section{Corresponding author: delciamp@fmrp.usp.br}

Manuscript received: September 2017 Manuscript accepted: November 2017 Version of record online: December 2017

\author{
Luiz A Del Ciampo', Adriana L Louro', leda R L Del Ciampo², \\ Ivan S Ferraz ${ }^{1}$
}

\begin{abstract}
Introduction: Adolescence is the period of transition between childhood and adult life, characterized by changes in physical, emotional, sexual and social development. Although during this phase most individuals are healthy, it is known that health status is related to behaviors and habits such as a healthy diet, the regular practice of physical activity and good sleep quality, which contribute to optimum physical and cognitive performance
\end{abstract}

Objective: To determine some sleep characteristics of adolescents living in the city of Ribeirão Preto (SP).

Methods: This was a cross-sectional descriptive study conducted at 14 schools in the city of Ribeirão Preto (SP) including adolescents aged 10 to 19 years who answered a questionnaire about sleep habits. The chi-square test was used to determine differences between genders with the aid of the EPI-INFO 7 software, with the level of significance set at $p<0.05$.

Results: A total of 535 adolescents (65\% girls) were included in the study. Of these, $47.7 \%$ studied during the morning period and $10.3 \%$ had a job and studied in the evening period. Regarding sleep duration, $242(45 \%)$ slept less than 9 hours per night during week days and $256(48 \%)$ during the weekends (Saturday and Sunday), Of the total number of adolescents studied, $75.5 \%$ reported that they went to bed when they felt sleepy, $90 \%$ reported delay in falling asleep, $84.3 \%$ used some type of electronic equipment before going to sleep, and $44 \%$ reported that they woke up during the night. In the morning, $70.3 \%$ needed to be awakened, and $44.7 \%$ reported a delay in waking up. During the daytime, $70 \%$ felt somnolent and $34 \%$ reported that they slept during the day. Girls reported that they felt more daytime sleepiness $(71.3 \%)$ and slept more during the day $(62.1 \%)$ than boys $(28.7 \%$ and $37.9 \%$, respectively), with the difference being statistically significant $(p<0.05)$.

Conclusions: Almost half the adolescents investigated sleep less than the minimum time considered ideal. Furthermore, the most of adolescents went to the bed when they felt sleepy, used electronic devices before to sleep, had difficulties to fall asleep, need to be awake in the morning and felt sleepy during the day. A substantial proportion of adolescents studied awoke at night and slept during the day. Compared to boys, girls felt sleepy and slept during the day significantly.

Keywords: adolescent, sleep, sleep hygiene, sleep stages

Suggested citation: Del Ciampo LA, Louro AL, Del Ciampo IRL, Ferraz IS. Characteristics of sleep habits among adolescents living in the city of Ribeirão Preto (SP). J Hum Growth Dev. 2017; 27(3): 307-314. DOI: http://dx.doi.org/10.7322/jhgd.107097 


\section{INTRODUCTION}

Adolescence is the period of transition between childhood and adult life, characterized by changes in physical, emotional, sexual and social development ${ }^{1}$. Although during this phase most individuals are healthy, it is known that health status is related to behaviors and habits such as a healthy diet, the regular practice of physical activity and good sleep quality, which contribute to optimum physical and cognitive performance ${ }^{2}$.

Sleep is an important physiological condition characterized by a reversible behavioral status with modifications of consciousness level and of responsiveness to internal and external stimuli ${ }^{3}$. The sleep-wake cycle is a circadian rhythm oscillating along a 24 hour period which is subject to the influence of factors such as the alternate light and dark period, school hours, working hours, leisure, and family activities. This biological rhythm is important for the maintenance of a schedule involving sleep, study, leisure and meals, with sleep being an important synchronizing factor between internal variations and environmental cycles. Sleep also plays an important role in the physical and emotional development of adolescents, who are going through a period of intense learning and differentiation. The adolescent is a being biologically programmed for sleep and later awakening, with his brain not experiencing a wakefulness state during most of the morning ${ }^{4}$. Even though there are individual variations due to genetic, environmental and sociocultural

\section{METHODS}

This was a cross-sectional, observational and descriptive study carried out from September to November 2013 at 14 public elementary and high schools in the city of Ribeirão Preto (SP), including adolescents ranging in age from 10 to 19 completed years. The schools were similar in terms of administrative characteristics (public elementary and middle schools), geographic location in the West sector of the city and representative of the socioeconomic profile of their students. In a first stage of the study, the schools were visited in order to present the research project and to invite the students to participate. On the occasion of a subsequent visit, the consent forms and the questionnaires regarding sleeping habits were distributed, and instructions about their filling out and date of collection were provided. In view of the possibility of absence of the students or forgetfulness, a limit of three visits was defined for the collection of the replies. The questionnaire used was a previously validated instrument that permitted to determine some characteristics related to sleep10 and to obtain information about age, sex, schooling, period of the day during which the student attends classes, hours and type of work, activities carried out during the period in which the student is not in school, time to go to sleep and to wake up on week days and weekends, what the student does before sleeping (reading, using the computer, games, telephone, music), whether he/she sleeps during the day, if he takes a long time to fall asleep, if he/she has daytime sleepiness, if his/her sleep is interrupted at night, if he/she wakes up by himself or needs to be awakened. The following criteria were factors, there is a recognized need for 9 or more hours of sleep per day during adolescence ${ }^{5,6}$.

In addition to the impact of these biological and environmental factors, the sleep patterns of adolescents can be significantly affected by social demands such as household tasks, extracurricular activities and work after school hours. Sleep-wake patterns vary widely during the week due to the habit of sleeping later on the weekends, as if to compensate for the accumulated sleep debt. This phenomenon, denoted "oversleeping", contributes to a break in the circadian rhythm and to reduced periods of daytime alertness ${ }^{7}$.

Because of the intense relationship existing between sleep and wakefulness quality, one of the more immediate results of sleep of poor quality is the fall in performance on the following day, with sleepiness, mood fluctuations, anxiety, low self-esteem, slow reasoning, loss of memory, poor school performance, and predisposition to accidents ${ }^{4,8,9}$.

In view of the importance of sleep for health during adolescence and considering the few studies available in Brazil about this topic, the objective of the present study was to determine some characteristics related to sleep among adolescents attending public schools located in the West region of the city of Ribeirão Preto (SP).

established to standardize the replies: a) taking a long time to fall asleep (more than 30 minutes); b) waking up too early (between 5:00 and 7:00 a.m.); c) sleeping during the day (more than 30 minutes), d) waking up at night (without considering trips to the bathroom). Inclusion criteria were: age of 10 to 19 years completed, agreeing to participate in the study, and giving written informed consent, also signed by a person responsible. Exclusion criteria were: pregnant girls, adolescents under treatment with drugs interfering with sleep (such as antidepressants and neuroleptics), presence of genetic syndromes and other diseases limiting habitual activities such as going to school, practicing sports, or working. The protocol and procedures of the study were approved by the Research Ethics Committee of the University Hospital, Faculty of Medicine of Ribeirão Preto, University of São Paulo (protocol $n^{\circ}$ 2760/2013). In addition to written informed consent signed by the students and the persons responsible for them, the authorization of the Regional Education Director's Office of Ribeirão Preto and of the Director's office of each teaching institution was also obtained. The absolute and relative frequency distribution of the Excel software (Windows 8) was used for the description of the variables stratified by sex, and the differences between proportions were analyzed by the chi-square test using the EPI-INFO ${ }^{7}$ software, with the level of significance set at $\mathrm{p}<0.05$. 


\section{RESULTS}

Of the 2264 eligible adolescents enrolled in the schools, 587 (25.9\%) returned the signed consent forms and the filled out questionnaires. However, 52 were excluded due to an incompletely filled out questionnaire, with $535(23.6 \%)$ adolescents being finally included in the study. Of these, 348 (65\%) were girls, 280 (52.3\%) studied in the afternoon and 55 (10.3\%) worked during one period of the day. Regarding sleep duration, 242 $(45 \%)$ slept less than 9 hours per night during week days and 256 (48\%) during the weekends (Saturday and Sunday), as shown in Table 1. Sleep duration on days with classes was less than 9 hours for $51.8 \%(97 / 187)$ of the boys and $46.8 \%(163 / 348)$ of the girls.

Table 1: Distribution of the number of hours of sleep according to week day and weekend and according to sex in adolescents attending public schools, Ribeirão Preto, 2013.

\begin{tabular}{lccccc}
\hline & \multicolumn{2}{c}{ Males } & \multicolumn{2}{c}{ Females } \\
Daily sleep time & $\mathbf{n}$ & $\mathbf{\%}$ & $\mathbf{n}$ & $\mathbf{\%}$ & $\mathbf{p}$ \\
\hline$<9$ h week & 79 & 32.6 & 163 & 67.4 & 0.394 \\
$<9$ h weekend & 75 & 29.3 & 181 & 70.7 & 0.113 \\
$\geq 9$ h week & 108 & 36.9 & 185 & 63.1 & 0.583 \\
$\geq 9$ h weekend & 112 & 39.8 & 167 & 60.2 & 0.144 \\
\hline
\end{tabular}

\section{$\mathbf{h}=$ hours}

Although $75.5 \%(404 / 535)$ of the adolescents reported that they went to bed when they felt sleepy, even so $89.7 \%(480 / 535)$ of them took a long time to fall a sleep. The use of some type of electronic equipment before going to sleep was reported by $84.3 \%$ (451/535) of the adolescents studied and 44\% (235/535) reported that they woke up during the night. In the morning, $70.3 \%$
(376/535) needed to be awakened and 44.7\% (239/535) reported that they took some time to wake up. Regarding the daytime period, $70 \%(373 / 535)$ reported that they felt somnolent, and $34 \%(181 / 535)$ reported that they slept during the day. These characteristics of sleep are presented in Table 2.

Table 2: Distribution of sleep characteristics of adolescents attending public schools according to sex. Ribeirão Preto 2013.

\begin{tabular}{|c|c|c|c|c|c|c|}
\hline \multirow[b]{2}{*}{ Sleep characteristics } & & \multicolumn{2}{|c|}{ Males } & \multicolumn{2}{|c|}{ Females } & \multirow[b]{2}{*}{$\mathbf{p}$} \\
\hline & & $\mathbf{n}$ & $\%$ & $\mathbf{n}$ & $\%$ & \\
\hline \multirow[t]{2}{*}{ Goes to bed when sleepy } & yes & 147 & 36.4 & 257 & 63.6 & 0.22 \\
\hline & no & 40 & 30.5 & 91 & 64.5 & \\
\hline \multirow[t]{2}{*}{ Takes time to fall asleep } & yes & 173 & 36.0 & 307 & 64.0 & 0.11 \\
\hline & no & 14 & 25.5 & 41 & 74.5 & \\
\hline \multirow[t]{2}{*}{ TV/PC/cellular phone/games/music player } & yes & 155 & 34.4 & 296 & 65.6 & 0.51 \\
\hline & no & 32 & 38.1 & 52 & 61.9 & \\
\hline \multirow[t]{2}{*}{ Wakes up during the night } & yes & 85 & 36.2 & 150 & 63.8 & 0.60 \\
\hline & no & 102 & 34.0 & 198 & 66.0 & \\
\hline \multirow[t]{2}{*}{ Takes time to wake up } & yes & 85 & 35.6 & 154 & 64.4 & 0.78 \\
\hline & no & 102 & 34.5 & 194 & 65.5 & \\
\hline \multirow[t]{2}{*}{ Wakes up by himself } & yes & 64 & 40.3 & 95 & 59.7 & 0.09 \\
\hline & no & 123 & 32.7 & 253 & 67.3 & \\
\hline \multirow[t]{2}{*}{ Daytime sleepiness } & yes & 107 & 28.7 & 266 & 71.3 & 0.04 \\
\hline & no & 80 & 49.4 & 82 & 50.6 & \\
\hline \multirow[t]{2}{*}{ Sleeps during the day } & yes & 53 & 29.3 & 128 & 70.7 & 0.04 \\
\hline & no & 134 & 37.9 & 220 & 62.1 & \\
\hline
\end{tabular}

TV: television PC: personal computer

The distribution of the number of hours of sleep according to study period and gender is presented in Table 3. Girls reported that they felt more daytime sleepiness $(71.3 \%)$ and slept more during the day $(62.1 \%)$ than boys ( $28.7 \%$ and $37.9 \%$, respectively), with the difference being statistically significant $(\mathrm{p}<0.05)$. No significant difference was observed between sexes regarding daytime sleepiness when attending classes in the morning $(88.6 \% / 78.1 \%)$ and in the afternoon $(65 \% / 35 \%)$. The distribution of the adolescents in terms of the report of daytime sleepiness according to sex and period of classes is presented in Table 4. 
Table 3: Distribution of the number of hours of sleep according to school period and according to sex in adolescents attending public schools. Ribeirão Preto. 2013.

\begin{tabular}{lcccccccccc}
\hline & \multicolumn{4}{c}{} & \multicolumn{4}{c}{$<\mathbf{9}$ hours } & \multicolumn{2}{c}{$\geq 9$ hours } \\
& \multicolumn{2}{c}{ male } & \multicolumn{2}{c}{ female } & \multicolumn{2}{c}{ male } & female & p \\
\hline Study period & $\mathrm{n}$ & $\%$ & $\mathrm{n}$ & $\%$ & $\mathrm{n}$ & $\%$ & $\mathrm{n}$ & $\%$ & \\
morning & 67 & 77.0 & 141 & 84.0 & 20 & 23.0 & 27 & 16.0 & 0.176 \\
evening & 12 & 12.0 & 22 & 12.2 & 88 & 88.0 & 158 & 87.7 & 0.956 \\
\hline
\end{tabular}

Table 4: Distribution of the adolescents reporting daytime somnolence according to sex and to sudy period sex in adolescents attending public schools, Ribeirão Preto, 2013.

\begin{tabular}{|c|c|c|c|c|c|c|c|c|c|}
\hline \multirow[b]{3}{*}{$\begin{array}{l}\text { Daytime } \\
\text { sleepiness }\end{array}$} & \multicolumn{4}{|c|}{ Morning } & \multicolumn{4}{|c|}{ Evening } & \multirow[t]{2}{*}{$p$} \\
\hline & \multicolumn{2}{|c|}{ male } & \multicolumn{2}{|c|}{ female } & \multicolumn{2}{|c|}{ male } & \multicolumn{2}{|c|}{ female } & \\
\hline & $n$ & $\%$ & $\mathrm{n}$ & $\%$ & $n$ & $\%$ & $\mathrm{n}$ & $\%$ & \\
\hline Yes & 68 & 78.1 & 149 & 88.6 & 39 & 39 & 117 & 65 & 0.182 \\
\hline No & 19 & 21.8 & 19 & 11.3 & 61 & 61 & 63 & 35 & 0.928 \\
\hline Total & 87 & 100 & 168 & 100 & 100 & 100 & 180 & 100 & \\
\hline
\end{tabular}

\section{DISCUSSION}

Sleep is considered to be an important indicator of health and quality of life and sleep deprivation is recognized as a factor that triggers various adverse consequences for individuals and for society ${ }^{11}$. The present study showed that, on week days, $42.2 \%$ of the boys and $46.8 \%$ of the girls sleep less than the 9 hours per night recommended for this age range, while on weekends these proportions increase to $59.8 \%$ and $47.9 \%$, respectively, in agreement with literature studies showing that adolescents sleep fewer hours than recommended. A recent meta-analysis of 41 studies on sleep habits among adolescents showed that the total number of hours of sleep during week days was 7.4, 8.3 and 7.6 for North American, European and Asian subjects, respectively ${ }^{12}$. Among 308 Australian adolescents aged 13 to 17 years, $36 \%$ slept less than 8 hours per night ${ }^{13}$. In 2013, Maume $^{14}$ reported that 974 adolescents living in Cincinnati (OH, USA), slept on average 7.8 hours per night, as also observed by Kilani et al. in a study of 802 adolescents from Oman $^{15}$.

A study on 250 adolescents attending Pittsburgh schools (PA, USA) revealed that their sleep period ranged from 6 to 7 hours on weekdays and from 7 to 8 hours on weekends ${ }^{16}$. In a study of 15,364 US adolescents aged 15 to 18 years, Meldrun \& Restivo ${ }^{17}$ observed that $68.5 \%$ of them slept less than 8 hours per night, a result similar to that reported by Pabayo et al. in a study of North American adolescents aged 14 to 19 years who slept, on average, 398 minutes per night ${ }^{18}$.

A multicenter study of 117,888 European adolescents detected a mean sleep time per night of 7.7 hours ${ }^{19}$. Maslowsky et al. also detected a reduction of sleep hours per night among 15,701 US adolescents, who slept on average 8.5 hours per night at 13 years of age and who reduced this time to 7.3 hours at 18 years of age ${ }^{20}$. Between 1991 and 2007, Barnes and Meldrum ${ }^{21}$ studied 287 pairs of monozygotic twins aged on average 15.7 years who belong to the National Longitudinal Study of Adolescent Health, USA, and observed that the mean time of hours of sleep was 7.7 hours.

Adolescents who sleep little have a greater chance to adopt other unhealthy habits ${ }^{22,23}$ such as physical inactivity, inadequate eating habits, and sedentary behaviors ${ }^{24}$. Sleepiness can interfere with school performance and with the willingness to go to school, in addition to generating less personal satisfaction, an increased number of diseases and feelings of irritation and anger ${ }^{25}$. A shorter nighttime sleep is also associated with greater alcohol, tobacco and drug consumption, with high risk sexual behaviors, overweight ${ }^{2}$, inappropriate eating habits ${ }^{26}$, and suicidal ideation ${ }^{27}$.

It has been reported that changes in sleeping behavior during adolescence are due to increased school requirements, social activities and holding a job, as well as other activities such as watching television and navigating on the internet, which may contribute to a delayed bedtime and to daytime sleepiness ${ }^{28,29}$. The most direct consequence of inadequate sleep for adolescents is sleepiness, which manifests in a more significant manner as difficulty in waking up at the proper time to go to school and in participating in situations of low stimulation such as reading activities during classes ${ }^{30}$.

A study conducted in Sweden and Estonia on 2,241 adolescents aged 15 to 16 years indicated that $25 \%$ of them slept less than 9 hours per night and that this reduced sleep time was negatively associated with poor school performance and with an increased number of absences ${ }^{30}$. A study on Norwegian adolescents reported that $32.3 \%$ of them slept less than 8 hours per night and also practiced few physical activities, with excessive use of television and computer and no defined times for meals ${ }^{31}$. The mean number of hours of sleep per night was eight among 3,311 
adolescents from different European countries. Those who slept less were the more sedentary ones, had a higher body mass index and greater body fat and ate less healthy foods ${ }^{32,33}$

Some authors have demonstrated that sleep duration is reduced among adolescents with advancing age a $^{4,28,34,35}$. Knutson et al. compared sleep duration in a sample of Australian young people between 1985 and 2004 and observed a reduction of hours of sleep in the second evaluation compared to the first. In addition, boys went to sleep later than girls in 2004, a difference that was not observed in the first evaluation ${ }^{36}$. Some studies of sleep duration during the second decade of life have also been conducted in Brazil. Among 1,126 adolescents aged 13 to 20 years enrolled in high school in the city of Santa Maria/RS, $54.8 \%$ slept 8 hours or less before the days with classes $^{37}$. A study of 863 schoolchildren in the second decade of life living in the city of São Paulo revealed that their mean sleep duration during weekdays was 8.8 hours and that the prevalence of adolescents who slept 8 hours or less during days of classes was 39\%. The main variable associated with less than 8 hours of sleep was age, with a reduction of sleep hours occurring with the advance of adolescence ${ }^{28}$. Among 92 adolescents enrolled in public schools in the city of São Paulo, the mean number of hours of sleep was 8.838 and sleep time was found to be related to age range more than to sex.

Factors such as school hours at the beginning of the day ${ }^{39}$ and holding a job ${ }^{37}$ can also interfere with sleep patterns and contribute to reduced sleep duration during adolescence, being associated with problematic behaviors such as worse school performance and limited time spent with the family or devoted to the practice of physical exercises. A study of Brazilian adolescents reported that, regardless of economic class, the period of school classes was strongly associated with sleep duration, indicating that those who studied or worked during the morning had greater sleep deprivation ${ }^{28}$. A recent Brazilian study conducted on more than eleven thousand adolescents aged 15 to 19 years living in the state of Santa Catarina pointed out that the prevalence of individuals who sleep less than 8 hours per night has increased from $31.2 \%$ in 2001 to $45.9 \%$ in 2011, reflecting the modifications in life habits imposed on adolescents during the last decade ${ }^{40}$.

The activities carried out by adolescents between lying down in bed and starting to sleep have been a subject of interest on the part of many investigators. In the present study, we observed that $84.3 \%$ of the adolescents used some type of electronic equipment before sleeping. Noland et al. reported that adolescents state that they use some strategies in order to fall asleep or remain awake, the most used strategy being watching television $(46.2 \%)^{41}$. Data of a WHO survey of the health conditions of adolescents from

\section{CONCLUSION}

Almost half the adolescents investigated sleep less than the minimum time considered ideal. Furthermore, the most of adolescents went to the bed when they felt sleepy, used electronic devices before to sleep, had difficulties to fall asleep, need to be awake in the morning
41 countries demonstrated that $61 \%$ to $70 \%$ of them watch television for more than two hours per day ${ }^{42}$.

A study conducted in England on adolescents aged 11 to 13 years observed that the use of technology (television, videogames, telephone, and social networks) was inversely associated with sleep duration, which was reduced on average by 1 hour when compared to adolescents who did not use these types of technology ${ }^{4,43}$. Zhou et al. ${ }^{44}$ have reported the detection in their results of some mechanisms whereby the use of electronic equipment may impair sleep quality, such as their use as a form of leisure at any time during the day or night, extending over long periods with no definition of beginning or ending time; the use of this type of sedentary entertainment alters the architecture of sleep, resulting in poor sleep quality; exposure to the screen luminosity near the time for rest may affect the sleep cycle by nighttime salivary suppression of melatonin; the use of electronic equipment may increase the level of activity of the nervous system and result in elevated alertness, psychological excitement and difficulty in falling asleep. Also, television programs and videogames were pointed out as factors interfering with sleep due to their excessively violent and/or stimulating content, possibly inhibiting relaxation and resulting in anxiety and difficulty in falling asleep ${ }^{40}$.

These factors were similar to those reported by Mesquita \& Reimão ${ }^{45}$ who showed that increased time of computer use by adolescents was associated with shorter sleep duration and a poorer perception of sleep quality. In another study conducted on 136,589 Korean adolescents, it was observed that the smaller number of sleep hours due to excessive use of the computer and of the internet was associated with emotional disorders such as depressive symptoms and suicidal ideation ${ }^{27}$.

The limitations of the present study are the fact that the investigation was conducted on a relatively small number of adolescents who study in schools of only one region in the city and that the data were obtained by selfevaluation, possibly leading to an overestimate of sleep time. In addition, by being a cross-sectional study, it may have reflected seasonal habits that are not maintained during other periods of the year. On the other hand, the relevant information obtained here about the sleep characteristics of adolescents can be added to that obtained in other studies, providing a base for the implantation of actions directed at the improvement of sleep quality and consequently of general health conditions ${ }^{46}$.

Learning about these conditions, allied to the peculiarities of adolescence, should be the basis for the counseling of the adolescents themselves and their relatives about health care, with priority given to actions involving sleep hygiene, which should be fully included in Hebiatry programs.

and felt sleepy during the day. A substantial proportion of adolescents studied awoke at night and slept during the day. Compared to boys, girls felt sleepy and slept during the day significantly. 


\section{REFERENCES}

1. Brand S, Kirov R. Sleep and its importance in adolescence and in common adolescent psychiatric conditions. Int J Gen Med. 2011;4:425-42. DOI: http://dx.doi.org/10.2147/IJGM.S11557

2. Owens J, Au R, Carskadon M, Millman R, Wolfson A, Braverman Pk, et al. Insufficient sleep in adolescents and young adults: an update on causes and consequences. Pediatrics. 2014;134(3):e92132. DOI: http://dx.doi.org/10.1542/peds.2014-1696

3. Porkka-Heiskanen T, Zitting KM, Wigren HK. Sleep, its regulation and possible mechanisms of sleep disturbances. Acta Physiol. 2013;208(4):311-28. DOI: http://dx.doi.org/10.1111/apha.12134

4. Foti KE, Eaton DK, Lowry R, McKnight-Ely LR. Sufficient sleep, physical activity, and sedentary behaviors. Am J Prev Med. 2011;41(6):596-602. DOI: http://dx.doi.org/10.1016/j.amepre.2011.08.009

5. Grandner MA, Patel NP, Gehrman PR, Perlis ML, Pack AI. Problems associated with short sleep: bridging the gap between laboratory and epidemiological studies. Sleep Med Rev. 2010;14(4):239-47. DOI: http://dx.doi.org/10.1016/j.smrv.2009.08.001

6. Williams JA, Zimmerman FJ, Bell F. Norms and trends of sleep time among US children and adolescents. JAMA Pediatr 2013;167(1):55-60. DOI: http://dx.doi.org/10.1001/jamapediatrics.2013.423

7. Kurth S, Jenni OG, Riedner BA, Tononi G, Carskadon MA, Huber R. Characteristics of sleep slow waves in children and adolescents. Sleep. 2010; 33(4):475-80. DOI: https://dx.doi.org/10.1093/sleep/33.4.475

8. Bartel KA, Gradisar M, Williamson P. Protective and risk factors for adolescent sleep: a meta-analytic review. Sleep Med Rev. 2015;21:72-85. DOI: https://dx.doi.org/10.1016/j.smrv.2014.08.002

9. Paiva T, Gaspar T, Matos MG. Sleep deprivation in adolescents: correlations with health complaints and health-related quality of life. Sleep Med. 2015;16(4):521-7. DOI: https://dx.doi.org/10.1016/j.sleep.2014.10.010

10. Piazzetta E, Del Ciampo LA, Zeppone SC. Características de sono e atividade física entre adolescentes do município de São Carlos (SP). Rev Bras Pesq Saúde. 2014;16(4):113-9. DOI: https://doi.org/10.21722/rbps.v16i4.11191

11. Bat-Piatault F, Fonseca $D$. Réduction du temps de sommeil chez les adolescents: conséquences et prise en charge? Arch Ped. 2012;19(10):1095-9. DOI: https://doi.org/10.1016/j.arcped.2012.07.004

12. Gradisar M, Gardner G, Dohnt H. Recent worldwide sleep patterns and problems during adolescence: a review and meta-analysis of age, region, and sleep. Sleep Med. 2011;12(2):110-18. DOI: https://dx.doi.org/10.1016/j.sleep.2010.11.008

13. Short MA, Gradisar M, Lack L, Wright H, Dewald J, Wolfson A, et al. A Cross-cultural comparison of sleep duration between US and Australian adolescents: the effect of school start time, parent-set bedtimes, and extracurricular load. Health Educ Behav. 2013;40(3):323-30. DOI: https://dx.doi.org/10.1177/1090198112451266

14. Maume DJ. Social ties and adolescent sleep disruption. J Health Soc Behav. 2013;54(4):498-515. DOI: https://dx.doi.org/10.1177/0022146513498512

15. Kilani H, Al-Hazzaa H, Waly MI, Musaiger A. Lifestyle habits: Diet, physical activity and sleep duration among Omani adolescents. Sultan Qaboos Univ Med J. 2013;13(4):510-9.

16. Matthews KA, Hall M, Dahl RE. Sleep in healthy black and white adolescents. Pediatrics. 2014;133(5):e1189-96. DOI: https://dx.doi.org/10.1542/peds.2013-2399

17. Meldrum RC, Restivo E. The behavioral and health consequences of sleep deprivation among US high school students: relative deprivation matters. Prev Med. 2014;63:24-8. DOI: https://dx.doi.org/10.1016/j.ypmed.2014.03.006

18. Pabayo R, Molnar BE, Street N, Kawachi I. The relationship between social fragmentation and sleep among adolescents living in Boston, Massachussetts. J Public Health. 2014;36(4):587-98. DOI: https://doi.org/10.1093/pubmed/fdu001

19. Sarchiapone M, Mandelli L, Carli V, losue M, Wasserman C, Hadlaczky G, et al. Hours of sleep in adolescents and its association with anxiety, emotional concerns, and suicidal ideation. Sleep Med. 2014;15(2):248-54. DOI: https://dx.doi.org/10.1016/j.sleep.2013.11.780

20. Maslowsky J, Ozer EJ. Developmental trends in sleep duration in adolescence and young adulthood: Evidence from a national United States sample. J Adolesc Health. 2014;54(6):691-7. DOI: https://dx.doi.org/10.1016/j.jadohealth.2013.10.201

21. 21. Barnes JC, Meldrun RC. The impact of sleep duration on adolescent development: a genetically informed analysis of identical twin pairs. J Youth Adolesc. 2014;44(2):1-18. DOI: https://dx.doi.org/10.1007/s10964-014-0137-4 
22. Yen CF, King BH, Tang TC. The association between short and long nocturnal sleep durations and risky behaviours and the moderating factors in Taiwanese adolescents. Psychiatry Res. 2010;179(1):69-74. DOI: https://dx.doi.org/10.1016/j.psychres.2009.02.016

23. McKnight-Eily LR, Eaton DK, Lowry R, Croft JB, Presley-Cantrell L, Perry GS. Relationships between hours of sleep and health-risk behaviors in US adolescent students. Prev Med. 2011;53(4-5):271-3. DOI: https://dx.doi.org/10.1016/j.ypmed.2011.06.020

24. Short MA, Gradisar M, Gill J, Camfferman D. Identifying adolescent sleep problems. PloS One. 2013;8(9):e75301. DOI: https://doi.org/10.1371/journal.pone.0075301

25. Colrain IM, Baker FC. Changes in sleep as a function of adolescent development. Neurophysicol Rev. 2011;21(1):5-21. DOI: https://dx.doi.org/10.1007/s11065-010-9155-5

26. Weiss A, Xu F, Storfer-Isser A, Thomas A, levers-Landis CE, Redline S. The association of sleep duration with adolescents' fat and carbohydrate consumption. Sleep. 2010;33(9):1201-9. DOI: https://doi.org/10.1093/sleep/33.9.1201

27. Do YK, Shin E, Bautista MA, Foo K. The associations between self-reported sleep duration and adolescent health outcomes: What is the role of time spent on Internet use? Sleep Med. 2013;14(2):195200. DOI: https://dx.doi.org/10.1016/j.sleep.2012.09.004

28. Bernardo MPSL, Pereira EF, Louzada FM, D’Almeida V. Sleep duration in adolescents of different socioeconomic status. J Bras Psiquiatr. 2009;58(4):231-7. DOI: http://dx.doi.org/10.1590/S0047-20852009000400003

29. Nuutinen T, Roos E, Ray C, Villberg J, Välimaa R, Rasmussen M, et al . Computer use, sleep duration and health symptoms: a cross-sectional study of 15-year olds in three countries. Int J Public Health. 2014;59(4):619-28. DOI: https://dx.doi.org/10.1007/s00038-014-0561-y

30. Ortega FB, Ruiz JR, Labayen I, Kwak L, Harro J, Oja L, et al. Sleep duration and activity levels in Estonian and Swedish children and adolescents. Eur J App Physiol. 2011;111(10):2615-23. DOI: https://dx.doi.org/10.1007/s00421-011-1883-6

31. Stea T, Knutsen T, Torstveit MK. Association between short time in bed, health-risk behaviors and poor academic achievement among Norwegian adolescents. Sleep Med. 2014;15(6):666-71. DOI: https://dx.doi.org/10.1016/j.sleep.2014.01.019

32. Garaulet M, Ortega FB, Ruiz JR, Rey-Lopes JP, Beghin L, Manyos Y, et al. Short sleep duration is associated with increased obesity markers in European adolescents: effect of physical activity and dietary habits. The HELENA study. Int J Obes. 2011;35(10):1308-17. DOI: https://dx.doi.org/10.1038/ijo.2011.149

33. Mitchell JA, Rodriguez D, Schmitz HK, Audrain-McGovern J. Sleep duration and adolescent obesity. Pediatrics. 2013;131:e1428-34. DOI: https://dx.doi.org/10.1542/peds.2012-2368

34. Eaton DK, McKnight-Eily LR, Lowry R, Perry GS, Presley-Cantrell L, Croft JB. Prevalence of insufficient, borderline and optimal hours of sleep among high school students-United States, 2007. J Adolesc Health. 2010;46(4):399-401. DOI: https://dx.doi.org/10.1016/j.jadohealth.2009.10.011

35. Olds T, Blunden S, Perkov J, Forchino F. The relationships between sex, age, geography and time in bed in adolescents: a meta-analysis of data from 23 countries. Sleep Med Rev. 2010;14(6):371-8. DOI: https://dx.doi.org/10.1016/j.smrv.2009.12.002

36. Knutson KL, van Cauter E, Rathouz PJ, DeLeire T, Lauderdale DS. Trends in the prevalence of short sleepers in the USA: 1975-2006. Sleep. 2010;33(1):37-45. DOI: https://doi.org/10.1093/sleep/33.1.37

37. Pereira EF, Bernardo MPSL, D’Almeida V, Louzada FM. Sono, trabalho e estudo: duração do sono em estudantes trabalhadores e não trabalhadores. Cad Saúde Pública. 2011;27(5):975-84. DOI: http://dx.doi.org/10.1590/S0102-311X2011000500015

38. Teixeira LR. Lowden A, Turte SL, Nagai R, Moreno CR, Latorre MR, et al. Sleep and sleepiness among working and non-working high school evening students. Chronobiol Int. 2007;24(1):99-113. DOI: http://dx.doi.org/10.1080/07420520601139763

39. Carskadon M, Acebo C, Jenni OG. Regulation of adolescent sleep: implications for behavior. Ann N Y Acad Sci. 2004;1021:276-91. DOI: http://dx.doi.org/10.1196/annals.1308.032

40. Hoefelmann L, Lopes AS, Silva KS, Moritz P, Nahas MV. Sociodemographic factors associated with sleep quality and sleep duration in adolescents from Santa Catarina, Brazil: what changed between 2001 and 2011? Sleep Med. 2013;14(10):1017-23. DOI: http://dx.doi.org/10.1016/j.sleep.2013.05.015

41. Noland H, Price JH, Dake J, Telljohann SK. Adolescents' sleep behaviors and perceptions of sleep. J Sch Health. 2009;79(5):224-30. DOI: http://dx.doi.org/10.1111/j.1746-1561.2009.00402.x

42. Hallal PC, Wells JC, Reichert FF, Anselmi L, Victora CG. Early determinants of physical 
activity in adolescence: prospective birth cohort study. BMJ. 2006;332(7548):1002-7.

DOI: http://dx.doi.org/10.1136/bmj.38776.434560.7C

43. Arora T, Broglia E, Thomas Neil, Taheri S. Associations between specific technologies and adolescent sleep quantity, sleep quality, and parasomnias. Sleep Med. 2014;15(2):240-7. DOI: http://dx.doi.org/10.1016/j.sleep.2013.08.799

44. Zhou HQ, Shi WB, Wanf XF, Yao M, Cheng GY, Chen PY, et al. An epidemiological study of sleep quality in adolescents in South China: a school $\square$ based study. Child Care Health Dev. 2012;38(4):581-7. DOI: http://dx.doi.org/10.1111/j.1365-2214.2011.01300.x

45. Mesquita G, Reimão R. Nightly use of computer by adolescents: its effect on quality of sleep. Arq NeuroPsiquiatr. 2007;65(2b):428-32. DOI: http://dx.doi.org/10.1590/S0004-282X2007000300012

46. Clinkinbeard SS, Simi P, Evans MK, Anderson AL. Sleep and delinquency: does the amount of sleep matter? J Youth Adolesc. 2011;40(7):916-30. DOI: http://dx.doi.org/10.1007/s10964-010-9594-6

\section{Resumo}

Introdução: A adolescência é o período de transição entre a infância e a vida adulta, caracterizada por mudanças no desenvolvimento físico, emocional, sexual e social. Embora durante esta fase a maioria dos indivíduos seja saudável, sabe-se que o estado de saúde está relacionado a comportamentos e hábitos tais como dieta saudável, prática regular de atividade física e boa qualidade do sono, que contribuem para o desempenho físico e cognitivo ideal.

Objetivo: Determinar algumas características do sono de adolescentes que vivem na cidade de Ribeirão Preto (SP).

Método: Trata-se de um estudo descritivo transversal realizado em 14 escolas da cidade de Ribeirão Preto (SP), incluindo adolescentes de 10 a 19 anos que responderam a um questionário sobre hábitos de sono. O teste do qui-quadrado foi usado para determinar diferenças entre gêneros com o software EPI-INFO 7, com o nível de significância definido em $p<0,05$.

Resultados: 535 adolescentes (65\% meninas) foram incluídos no estudo. Destes, $47,7 \%$ estudavam durante o período da manhã e $10,3 \%$ trabalhavam e estudavam no período da noite. Em relação à duração do sono, $242(45 \%)$ dormiram menos de 9 horas por noite durante a semana e $256(48 \%)$ durante os fins de semana (sábado e domingo). Do total de adolescentes estudados, $75,5 \%$ relataram que foram para a cama quando sentiam sono, $90 \%$ relataram atraso em adormecer, $84,3 \%$ usaram algum tipo de equipamento eletrônico antes de dormir e $44 \%$ relataram que acordaram durante a noite. No período da manhã, $70,3 \%$ precisavam ser despertados, e $44,7 \%$ relataram atraso no despertar. Durante o dia, $70 \%$ sentiram-se sonolentos e $34 \%$ relataram que dormiam durante o dia. As meninas relataram que sentiram mais sonolência diurna $(71,3 \%)$ e dormiam mais durante o dia $(62,1 \%)$ que os meninos ( $28,7 \%$ e $37,9 \%$, respectivamente), sendo a diferença estatisticamente significante $(p<0,05)$.

Conclusão: Quase metade dos adolescentes investigados dorme menos que o tempo mínimo considerado ideal. Além disso, a maioria dos adolescentes foi à cama quando sentiu sono, usou dispositivos eletrônicos antes de dormir, teve dificuldades em adormecer, precisava ser acordado pela manhã e sentiu sono durante o dia. Uma parcela substancial dos adolescentes estudados ficava acordada à noite e dormia durante o dia. Em comparação com os meninos, as meninas sentiram sono e dormiram durante o dia de forma significativa.

Palavras-chave: adolescente, sono, higiene do sono, estágios do sono

${ }^{-}$The authors (2017), this article is distributed under the terms of the Creative Commons Attribution 4.0 International License (http://creativecommons.org/licenses/by/4.0/), which permits unrestricted use, distribution, and reproduction in any medium, provided you give appropriate credit to the original author(s) and the source, provide a link to the Creative Commons license, and indicate if changes were made. The Creative Commons Public Domain Dedication waiver (http://creativecommons.org/publicdomain/ zero/1.0/) applies to the data made available in this article, unless otherwise stated. 